\title{
Variants of Currarino Syndrome: Embryological Association and Review of Pertinent Literature
}

\author{
Rahul Gupta, ${ }^{1}$ Shyam Bihari Sharma, ${ }^{1}$ Praveen Mathur, ${ }^{2}$ and Ram Babu Goyal ${ }^{2}$ \\ ${ }^{1}$ Department of Paediatric Surgery, NIMS Medical College and University, Jaipur 303121, India \\ ${ }^{2}$ Department of Paediatric Surgery, SMS Medical College, Jaipur 302004, India
}

Correspondence should be addressed to Rahul Gupta; meetsurgeon007@gmail.com

Received 21 July 2014; Accepted 18 October 2014; Published 9 November 2014

Academic Editor: Benjamin Feldman

Copyright (C) 2014 Rahul Gupta et al. This is an open access article distributed under the Creative Commons Attribution License, which permits unrestricted use, distribution, and reproduction in any medium, provided the original work is properly cited.

Currarino syndrome is a triad of sacral defect, anorectal malformation and a presacral mass. The diagnosis is usually made late in childhood and about 50\% of cases are familial with autosomal dominant inheritance. We present two neonates (one with vestibular fistula, and another with cloacal malformation) with the features consistent with Currarino syndrome, but with Altman's type II sacrococcygeal teratoma, that is, presacral mass having an external sacrococcygeal component also. We believe that this triad should be considered a variant of Currarino syndrome. In first case, excision of the mass along with coccyx, followed by primary Posterior Sagittal AnoRectoPlasty was performed in the same setting. The patient succumbed to death due to septicemia as a result of wound sepsis. Learning from the previous experience, we decided to do a diverting sigmoid loop colostomy followed by posterior sagittal excision of the mass along with coccyx, in same sitting in the second case. There was no recurrence. Though HLXB9 has been identified as the major causative gene in Currarino syndrome, exact pathogenesis is still unclear. We herein highlight the significance of this variant of Currarino syndrome and propose a theory on the basis of an embryological association between the malformation complex.

\section{Introduction}

The Currarino syndrome refers to a specific neurenteric malformation complex characterized by three main features, anorectal malformation (ARM), sacral defect, and a presacral mass, which may be an anterior sacral meningocele/teratoma/an enteric cyst or a combination of these [1]. ARM is usually of the low type. The condition is rare with approximately 200 cases reported in the literature. The triad was first described by Kennedy in 1926 [2]. Guido Currarino recognized these disorders as a syndrome and postulated the embryogenesis of the triad in 1981 [1]. About $50 \%$ of cases are familial with autosomal dominant inheritance. It is characterized by a partial agenesis of the sacrum (hemisacrum) typically involving sacral vertebrae S2-S5 only [3]. First sacral vertebra is always preserved [1]. We present two neonates, first with vestibular fistula and second with cloacal malformation with Altman's type II sacrococcygeal teratoma and partial sacral agenesis.

\section{Case 1}

A 2-day-old female baby was presented to us with absence of anal opening. Her birth weight was $2.7 \mathrm{~kg}$. On examination, there was vestibular fistula (Figure 1(a)) and a sacrococcygeal swelling about $4 \times 2.5 \mathrm{~cm}$ in size (Figures $1(\mathrm{~b})$ and $1(\mathrm{c})$ ).

Baseline blood investigations were normal. Radiogram revealed dilated loops of bowel, partial sacral agenesis with absence of 4th and 5th sacral vertebral segments and scimitarshaped sacrum (Figure 2(a)), and presacral soft tissue shadow with external component (Figure 2(b)). Ultrasound of the pelvis and sacral spine revealed solid-cystic mass in sacrococcygeal region extending up to the base of coccyx, with $15 \times 12 \mathrm{~mm}$ component externally. Further imaging was performed with computerized tomography (CT) scan and $2.6 \times 2.1 \times 3.8 \mathrm{~cm}$ well-defined hypodense lesion anterior to sacrum with anterior displacement of rectum with external sacrococcygeal component, consistent with Altman's type II sacrococcygeal teratoma, was seen (Figures 3 and 4). 


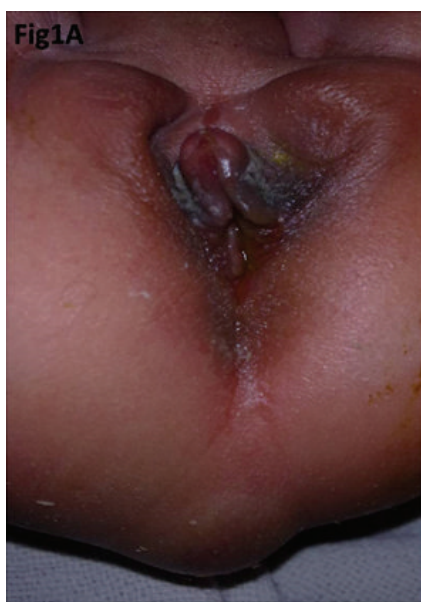

(a)

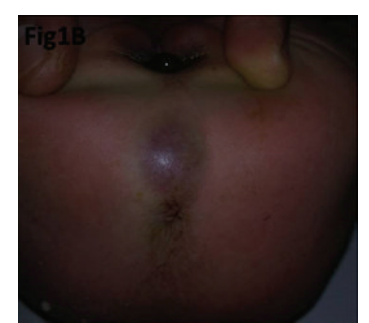

(b)

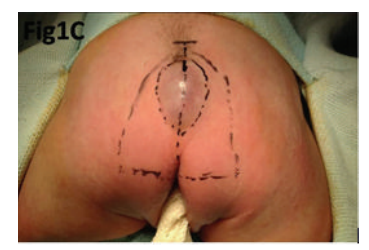

(c)
Figure 1: Preoperative photographs of a 2-day-old female neonate showing vestibular fistula (a) and a sacrococcygeal lesion ((b) and (c)).

Tumor markers were not performed because of nonavailability in our resource limited setup. Hegar's dilator number 6 could be easily inserted into the vestibular fistula. After performing rectal washes and bowel decompression, a decision for surgical excision of the mass was planned by posterior sagittal approach. Posterior sagittal incision was given from sacrum to posterior margin of the vestibule. The site of neoanus was identified using muscle stimulator. Posterior parasagittal fibers were cut exactly in the midline. The mass was identified, dissected meticulously, and completely excised. Posterior sagittal anorectoplasty was performed after excision of the mass and removal of the coccyx, after ensuring the good vascularity of the bowel. Histopathology revealed benign mature sacrococcygeal teratoma. Postoperatively, patient developed wound dehiscence. A diverting sigmoid loop colostomy was performed. Unfortunately patient developed septicemia due to wound sepsis and succumbed to death after 2 weeks.

\section{Case 2}

A 3-day-old female baby with birth weight of $2.5 \mathrm{~kg}$ with ARM and a sacrococcygeal swelling was presented to us. On examination she was having single perineal opening (Figure 5(a)) and a diagnosis of cloacal malformation was made. Sacrococcygeal swelling was about $2 \times 2 \mathrm{~cm}$ in size (Figure 5(b)). Radiological investigations also revealed partial sacral agenesis. Ultrasound of the pelvis and lumbar spine was consistent with Altman's type II sacrococcygeal teratoma. After preoperative work-up, a diverting sigmoid loop colostomy was performed, followed by posterior sagittal excision of the mass along with coccyx in the same setting. Tumor markers were not performed because of nonavailability in our resource limited setup. Histopathology was consistent with benign mature sacrococcygeal teratoma. Patient was discharged in a stable condition and there was no recurrence. The patient is under followup and definitive repair of cloacal malformation has been planned.
There was no familial occurrence of the Currarino syndrome in both cases. Unfortunately due to limited resources, no genetic testing could be performed and no biological material (sacrococcygeal tumor) could be retained.

\section{Discussion}

Currarino syndrome, Currarino triad, hereditary sacral agenesis, caudal regression spectrum, was also known in the past as ASP (anal atresia, sacral anomalies, presacral mass). We also believe that it is most exact to use the term syndrome to describe this condition as there are often other anomalies associated with this triad. Other associated symptoms and malformations include female internal genital anomalies, urinary tract anomalies, neonatal-onset bowel obstruction, chronic constipation, recurrent perianal sepsis, and tethered spinal cord $[4,5]$.

Altman's type IV sacrococcygeal teratoma (presacral) is one of the main features seen in Currarino syndrome, other than ARM and sacral defect. In our case, the two neonates were having the triad of ARM, sacral defect, and Altman's type II sacrococcygeal teratoma. First case was having low type anomaly, while the second one has high type defect.

This constellation of ARM, partial sacral agenesis, and Altman's type II sacrococcygeal teratoma, that is, presacral mass having external sacrococcygeal component, was felt to be consistent with Currarino syndrome. We believe that this triad should be considered a variant of Currarino syndrome. To the best of our knowledge, this variant of Currarino syndrome has not been reported in the literature.

The patient of Currarino syndrome may be diagnosed in the neonatal period, but the diagnosis is usually made late in childhood as the lesion may remain asymptomatic or be manifested by nonspecific symptoms such as constipation, rectal fullness, urinary symptoms like dysuria due to local pressure effect, lower abdominal pain, and meningitis [5]. In our cases the presentation was in the neonatal age, owing to the obvious swelling in the sacrococcygeal region and because of the absence of the anus in both cases.

Currarino syndrome is a distinct clinical entity, having sacral defect typically involving sacral vertebrae S2-S5 only, with preservation of first sacral vertebra. Isolated sacral agenesis can occur as a consequence of diabetic embryopathy where it is described as the caudal regression syndrome. The sacral defect tends to be more extensive, involving the first sacral vertebrae. Approximately $15-25 \%$ of mothers of these children have insulin dependent diabetes mellitus $[6,7]$. The other syndromes with sacral agenesis are VATER and OEIS syndromes. Maternal diabetes could not be elicited in our cases.

Currarino syndrome has a female predilection, especially in adults [8]. In our case, both neonates were also female. Plain radiographs reveal defects in the sacrum which was present in our case, with absence of few sacral vertebral segments and a scimitar-shaped sacrum. The scimitar sacrum is the most common of sacral anomalies $[8,9]$. Ultrasound reveals either a cystic lesion, uni- or multilocular cyst, or an associated tumor, if present. CT scan is quite useful to identify the sacral defect as well as the presacral mass, displacing 


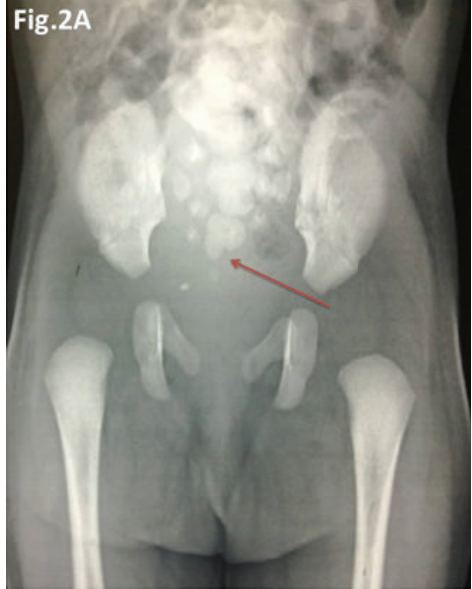

(a)

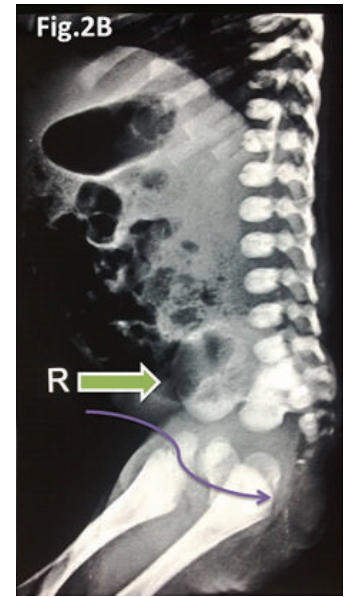

(b)

FIGURE 2: Radiographs of the patient showing partial sacral agenesis (red arrow) with absence of 4th and 5th sacral vertebral elements on left and a scimitar-shaped sacrum (a) with presacral soft tissue shadow (green arrow) with external (violet arrow) component (b).
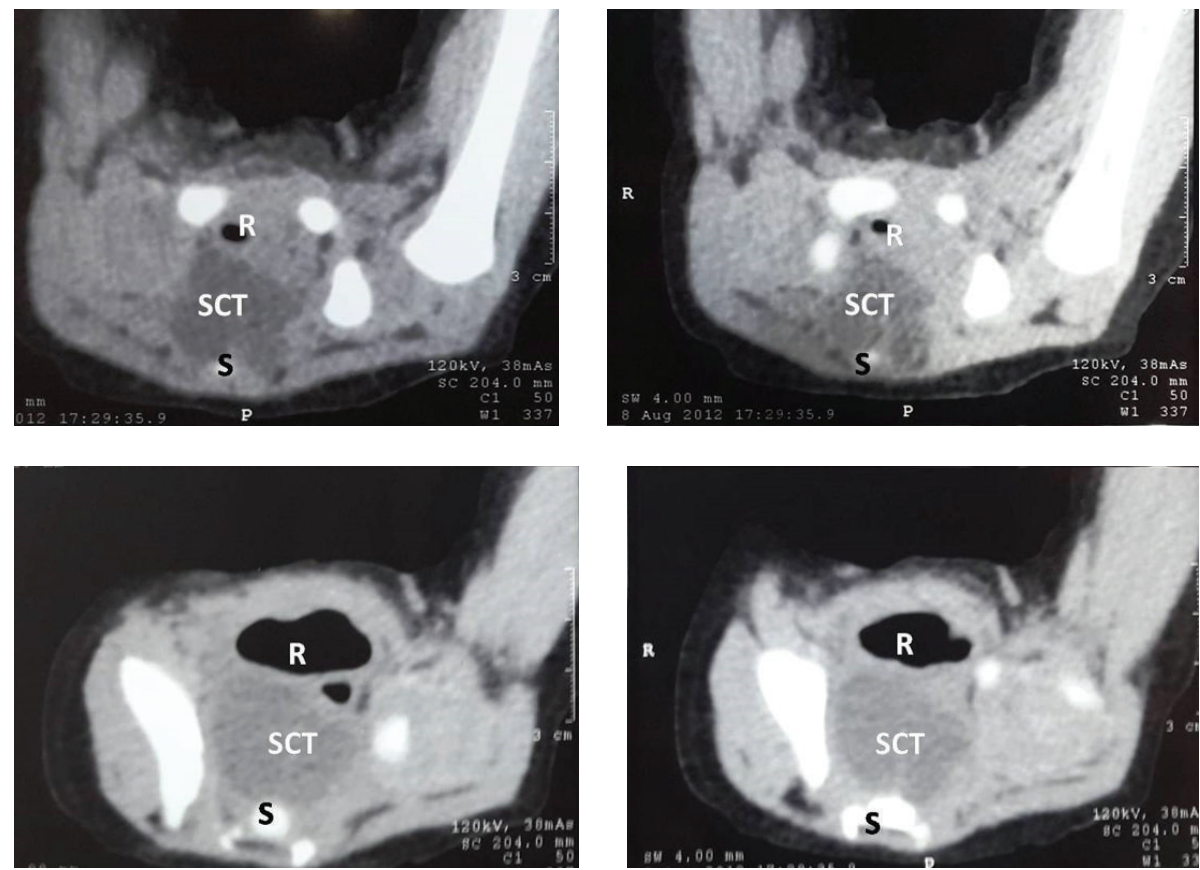

FIGURE 3: CT transverse section images showing well-defined hypodense lesion anterior to sacrum with anterior displacement of rectum. SCT: sacrococcygeal teratoma, R: rectum, S: sacrum.

the rectum anteriorly. Magnetic resonance imaging (MRI) in addition may demonstrate anomalies of the cord such as tethering [9].

Surgical management is recommended in all cases [9]. There is no spontaneous regression of sacrococcygeal teratoma in Currarino syndrome and it has reported mortality of $30 \%$ without surgery [3]. Defunctioning sigmoid colostomy is a practical decision for initial management. It should be followed by excision of the presacral lesion (or type II SCT with coccyx) and repair of anorectal malformation in the same or next setting [8].

Excision of the presacral lesion and repair of the anorectal malformation may be performed via posterior sagittal, abdominal, or combined approach [8]. As teratoma can have malignant potential, hence lies the importance of complete histopathological examination and also followup of these cases to detect any recurrence. Postoperative complications are not uncommon and may be due to injury to adjacent organs during dissection. Local abscess, meningitis, rectal fistula, and coagulopathy have been reported [1]

\section{Embryological Basis of Currarino Syndrome}

Though HLXB9 gene on 7q36 (chromosome 7q36) has been identified as the major causative gene in Currarino syndrome, positive in approximately $30 \%$ of the cases, exact 

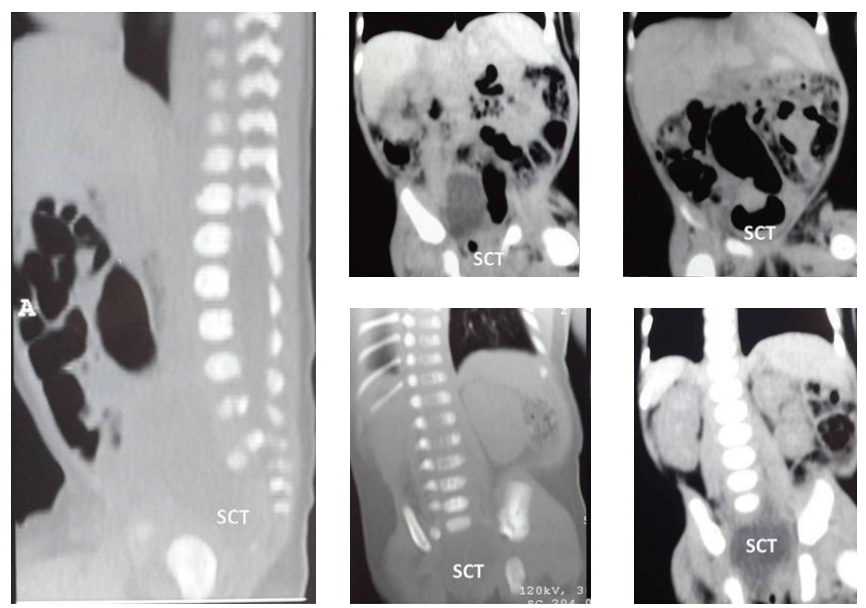

FIGURE 4: CT coronal and sagittal section images showing presacral hypodense lesion with external sacrococcygeal component consistent with Altman's type II sacrococcygeal teratoma. SCT: sacrococcygeal teratoma.

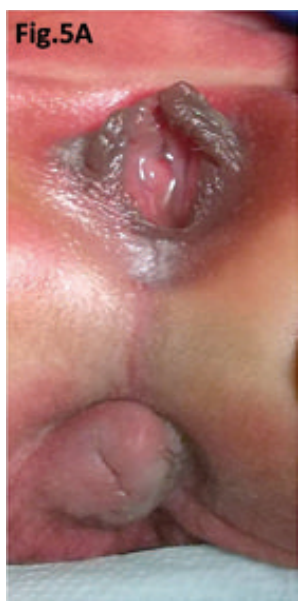

(a)

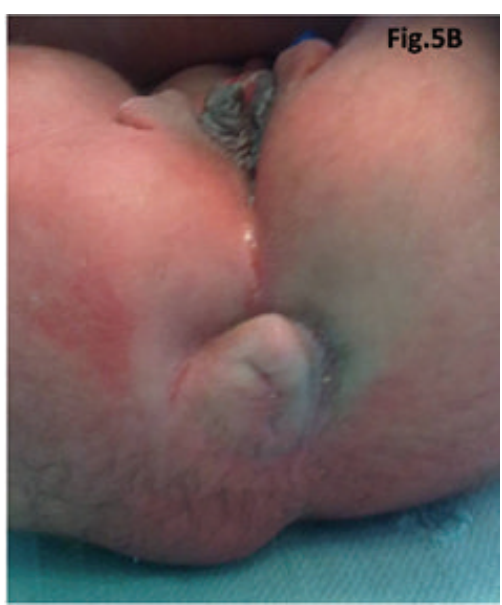

(b)

FIGURE 5: Preoperative photograph of a 3-day-old female neonate with single perineal opening (a) and sacrococcygeal lesion (b).

pathogenesis is still unclear [10]. Also most cases of deletion of human $7 \mathrm{q} 36$ do not have Currarino syndrome and interestingly only approximately half have haploinsufficiency for $\mathrm{SHH}$. Currarino believed that the primary splitting of the notochord and formation of a fistula between the gut with enteric elements ventrally and the spinal canal neural elements dorsally and consequent partial resorption of the fistula may give rise to a meningocele or an enteric cyst, the anorectal anomaly being a consequence of these early abnormal adhesions between the hind gut and the neural tube [1]. Currarino's model, Dias theory, and mouse model by Liu et al. have all thrown light on the pathogenesis $[1,11,12]$.

We propose a theory on the basis of an embryological association between the malformation complexes. Epiblasts cells migrating from primitive node and proximal part of primitive streak lead to the formation of notochord (Figure 6) and paraxial and intermediate plate mesoderm. Failure of some of these cells to migrate from primitive node will lead to defect at the caudal most aspect of notochord or the splitting of the notochord and formation of a fistula between the gut ventrally and the neural elements dorsally or vice versa, as also proposed by Currarino. Also failure of some of these cells to migrate from primitive node will lead to remnants at primitive streak which may persist in sacrococcygeal region as a teratoma [13].

HLXB9 gene is telomeric to the sonic hedgehog ( $\mathrm{SHH})$ gene on $7 \mathrm{q} 36$. We propose that loss of $\mathrm{SHH}$ may be contributory to associated malformations seen in Currarino syndrome. The caudal defect in the notochord and loss of $\mathrm{SHH}$ gene may have a cause and effect relationship and are speculative. SHH gene is responsible for maintaining midline barrier and is also responsible for various other functions. The interaction and interplay of $\mathrm{SHH}$ gene and noggin genes produced by the notochord with the ventromedial portion of somite lead to the differentiation of sclerotomes to form vertebrae. This cascade of reactions is further mediated by PAX1 gene [13]. Mutations in HLXB9 gene along with $\mathrm{SHH}$ genes functioning at the caudal level may explain partial 


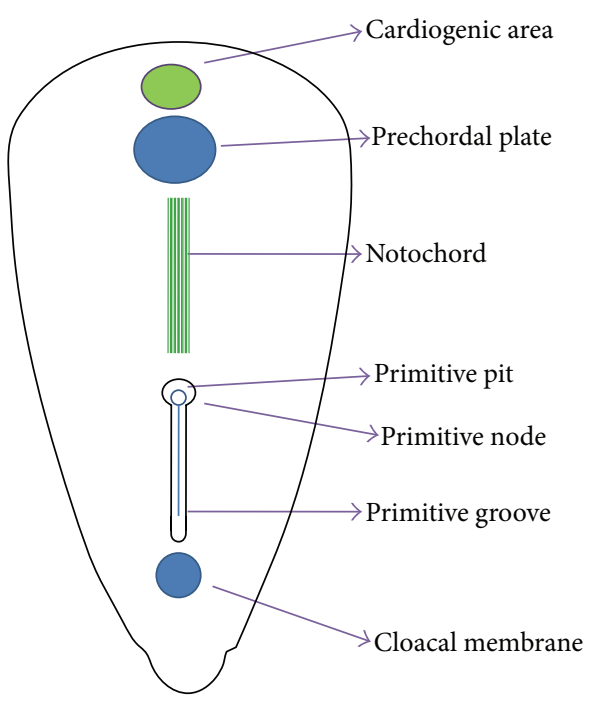

FIGURE 6: Formation of notochord by primitive streak.

sacral agenesis. Also rib anomalies may be explained on the basis of this theory [13].

Molecular regulation of gut tube development is also mediated through SHH gene. Epithelial mesenchymal interaction is initiated by $\mathrm{SHH}$ gene throughout gut tube and leads to regional specification, which occurs at the time of lateral body folding. SHH gene leads to upregulation of factors (HOX gene) in the mesoderm of distal midgut and hindgut leading to formation and differentiation of distal gut and cloaca [13]. The anorectal anomaly hence is due to failure of SHH gene and its interaction with urorectal septum.

\section{Conclusions}

The triad of ARM, sacral defect, and Altman's type II sacrococcygeal teratoma should be considered a variant of Currarino syndrome. We believe that malformation complex seen in the Currarino syndrome is due to the failure of migration of epiblasts cells from primitive node and proximal part of primitive streak leading to defect at the caudal most aspect of notochord or the splitting of the notochord and formation of a fistula between the gut ventrally and the neural elements dorsally. Also failure of some of these cells to migrate from primitive node will lead to remnants at primitive streak which may persist in sacrococcygeal region as a teratoma. Loss of sonic hedgehog ( $\mathrm{SHH}$ ) gene may explain the associated malformations seen in Currarino syndrome.

\section{Conflict of Interests}

The authors declare that there is no conflict of interests regarding the publication of this paper.

\section{Authors' Contribution}

Concepts were done by Rahul Gupta. Design was done by all authors. Definition of intellectual content was done by all authors. Literature search was completed by Rahul Gupta. Clinical studies were done by all authors. Experimental studies were done by Rahul Gupta. Data acquisition was done by Rahul Gupta. Data analysis was completed by all authors. Statistical analysis was completed by Rahul Gupta. Paper preparation was done by all authors. Paper editing was done by all authors. Paper review was completed by all authors. Guarantor was completed by Rahul Gupta.

\section{References}

[1] G. Currarino, D. Coln, and T. Votteler, "Triad of anorectal, sacral, and presacral anomalies," American Journal of Roentgenology, vol. 137, no. 2, pp. 395-398, 1981.

[2] R. L. J. Kennedy, "An unusual rectal polyp; anterior sacral meningocele," Surgery, Gynecology \& Obstetrics, vol. 43, p. 803, 1926.

[3] D. S. O'Riordain, P. R. O'Connell, and W. O. Kirwan, "Hereditary sacral agenesis with presacral mass and anorectal stenosis: the Currarino triad," British Journal of Surgery, vol. 78, no. 5, pp. 536-538, 1991.

[4] P. J. Emans, J. van Aalst, E. L. W. van Heurn et al., "The currarino triad: neurosurgical considerations," Neurosurgery, vol. 58, no. 5, pp. 924-928, 2006.

[5] H. Brem, B. L. Beaver, P. M. Colombani et al., "Neonatal diagnosis of a presacral mass in the presence of congenital anal stenosis and partial sacral agenesis," Journal of Pediatric Surgery, vol. 24, no. 10, pp. 1076-1078, 1989.

[6] A. J. Alles and K. K. Sulik, "A review of caudal dysgenesis and its pathogenesis as illustrated in an animal model," Birth Defects: Original Article Series, vol. 29, no. 1, pp. 83-102, 1993.

[7] C. L. Harlow, M. D. Partington, and G. A. Thieme, "Lumbosacral agenesis: clinical characteristics imaging, and embryogenesis," Pediatric Neurosurgery, vol. 23, no. 3, pp. 140-147, 1995.

[8] S. C. Lee, Y. S. Chun, S. E. Jung, K. W. Park, and W. K. Kim, "Currarino triad: Anorectal malformation, sacral bony abnormality, and presacral mass-a review of 11 cases," Journal of Pediatric Surgery, vol. 32, no. 1, pp. 58-61, 1997.

[9] K. S. Lee, D. J. Gower, J. M. McWhorter, and D. A. Albertson, "The role of MR imaging in the diagnosis and treatment of anterior sacral meningocele: report of two cases," Journal of Neurosurgery, vol. 69, no. 4, pp. 628-631, 1988.

[10] S. A. Lynch, Y. Wang, T. Strachan, J. Burn, and S. Lindsay, "Autosomal dominant sacral agenesis: currarino syndrome," Journal of Medical Genetics, vol. 37, no. 8, pp. 561-566, 2000.

[11] M. S. Dias and R. G. Azizkhan, "A novel embryogenetic mechanism for Currarino's triad: inadequate dorsoventral separation of the caudal eminence from hindgut endoderm," Pediatric Neurosurgery, vol. 28, no. 5, pp. 223-229, 1998.

[12] Y. Liu, F. Sugiyama, K. Yagami, and H. Ohkawa, "Sharing of the same embryogenic pathway in anorectal malformations and anterior sacral myelomeningocele formation," Pediatric Surgery International, vol. 19, no. 3, pp. 152-156, 2003.

[13] T. W. Sadler, Langman's Medical Embryology, Lippincott Williams \& Wilkins, Philadelphia, Pa, USA, 2006. 

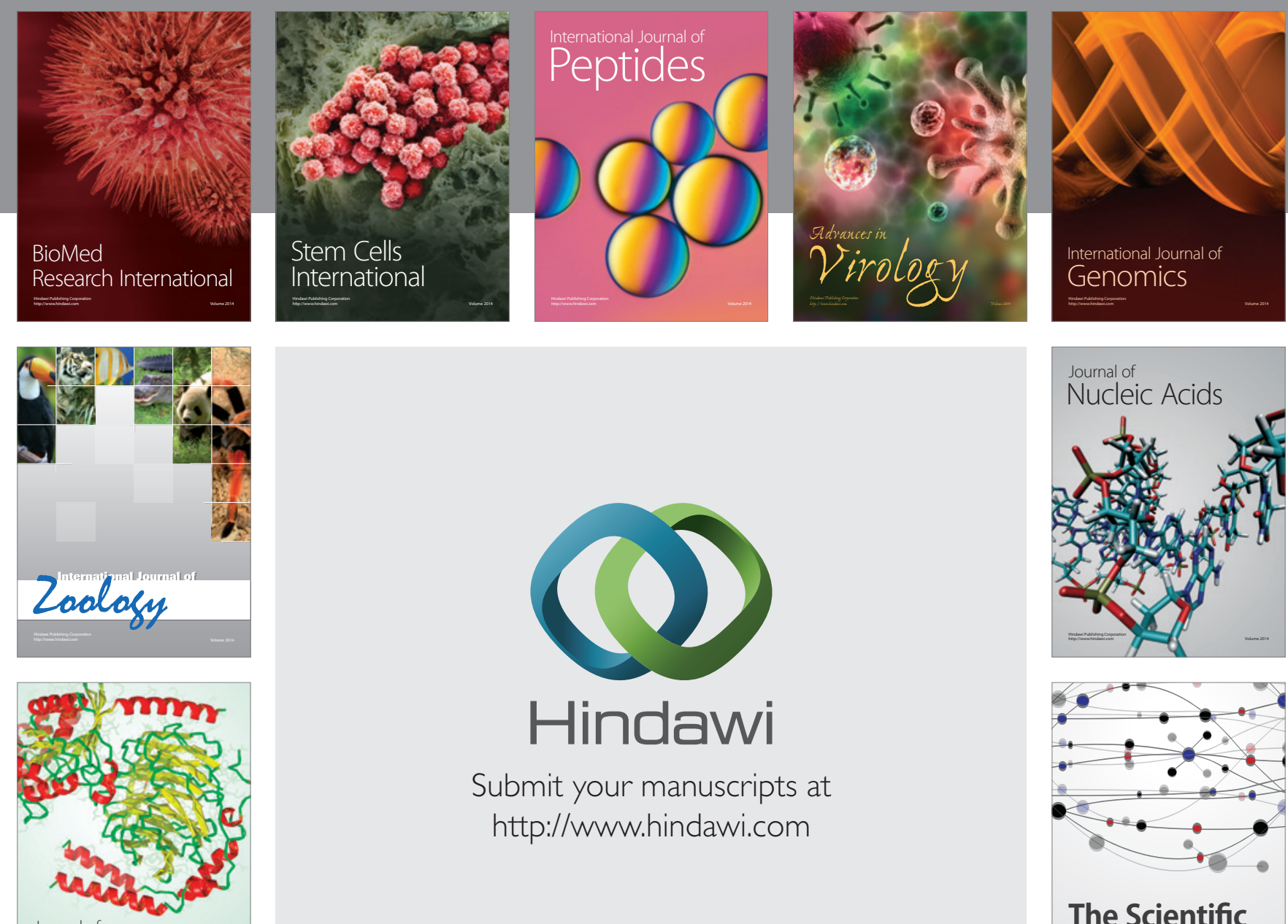

Submit your manuscripts at

http://www.hindawi.com

Journal of
Signal Transduction
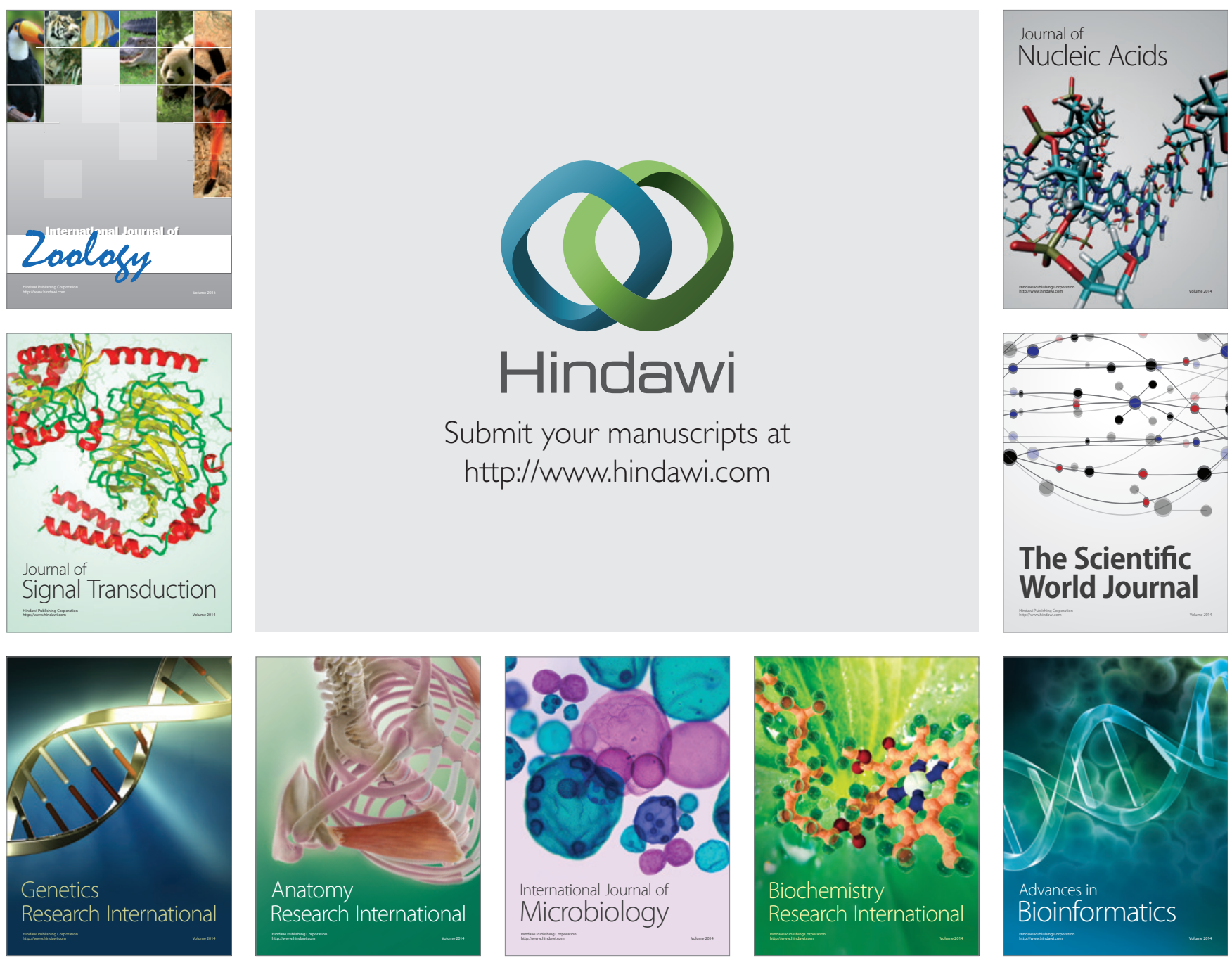

The Scientific World Journal
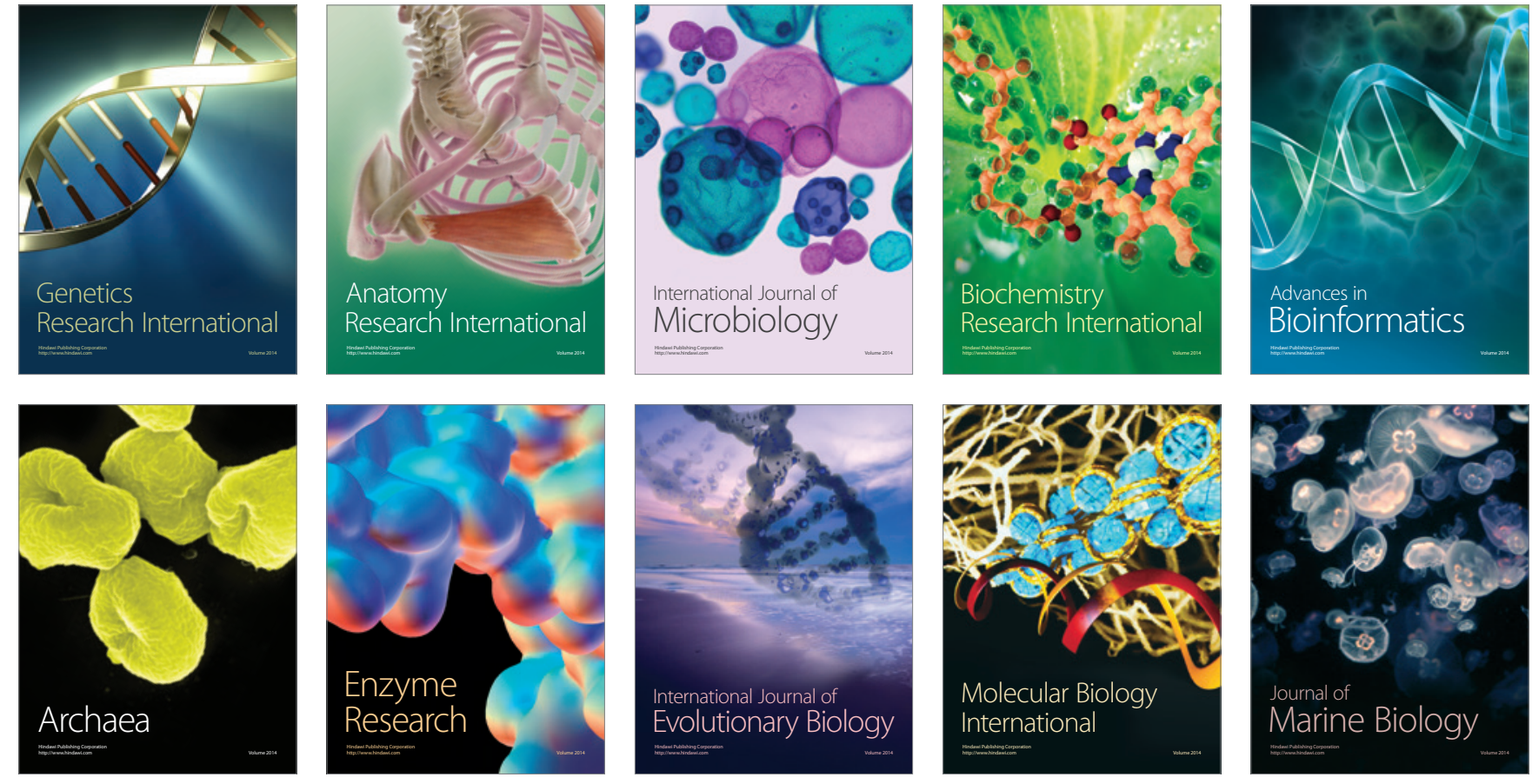